\section{Violence Against Women in the Rwandan Genocide}

\author{
Cecilia D'Arville \\ Sophomore, Global Studies/Journalism
}

Throughout history, genocides have proven to be amongst the most violent atrocities committed by the human race. The Rwandan genocide was no different. In 1994, between April and July, approximately 800,000 Rwandans were killed. ${ }^{1}$ Occurring only a couple decades ago, the Rwandan genocide stands out as one of the most notable examples of genocide in recent history. Despite the eyes of the world watching and involvement by the United Nations and other groups, hundreds of thousands of people were killed and sexually assaulted. During the Rwandan genocide, women were sexually assaulted on a scale previously unrecorded in any past genocide (United Nations 2014). ${ }^{2}$ Women in the Rwandan genocide are unique in their roles both as victims and perpetrators. This paper will explore violence against Tutsi women during the Rwandan genocide from April through July, 1994. Specifically, I will analyze the methods of such violence, the perpetrators, and the long-term effects on the female population.

Prior to discussing the violence against women, it is important to understand the pre-existing tensions in Rwanda which led to the genocide and the status of Tutsi women in Rwandan society. The two major groups involved in the genocide were the Hutus and the Tutsis; the Hutus accounted for 84 percent of the population and the Tutsi accounted for 15 percent. ${ }^{3}$ Although the groups are ethnically different, the main tensions between the two stemmed from political and socioeconomic differences (Hoex \& Smeulers 2010:438). The Tutsis were the elites of society, and the Hutus rebelled against them in the mid-1950s by taking over the government (Sharlach 1999:391). The Hutus controlled the government for the next few decades and implemented discriminatory policies against Tutsis, deepening the tensions between the groups (Hoex \& Smeulers 2010:439). In 1990, a Tutsi rebel group invaded Rwanda in an attempt to regain control of the government (Sharlach 1999:391). Their attempt failed and led Hutu leaders to begin planning what would become the Rwandan genocide.

Regardless of ethnicity, women in Rwanda held less power in society than men. The Family Code of 1992 designated husbands as the official heads of households, limiting the rights of women within their families (U.S. Department of State 1997). Moreover, no laws exist to guarantee a woman the right to inherit land and property if her husband dies (U.S. Department of State 1997). Before the genocide, women held very little political influence. In 1984, there were no women involved in the sexual assault from Hutu extremists and government supporters prior to the start of the genocide. For example, in the early 1980s, a campaign began against single urban women and women in relationships with European men (Taylor 1999:44). The majority of the women incarcerated during this campaign were Tutsi, many of whom were abused by their captors or raped (Taylor 1999:44). In the 1990s, being both Tutsi and female in Rwanda put these women at a higher risk for sexual violence compared to other female and ethnic populations. 
Violence in genocides most clearly manifests itself in the methodologies used to destroy the intended group. According to the United Nations definition, genocidal acts include "causing serious bodily or mental harm to members of the group [and] imposing measures intended to prevent births within the group" (1948:3). Some common tactics of genocide are public executions, mass killings, and starvation. Within the Rwandan genocide, the Hutu militia, also called the Interahamwe, used such methods to kill Tutsi men, women, and children. However, there was one method of genocide which existed within Rwanda that stood out: rape. Rape as a tool of genocide was present prior to the Rwandan genocide, such as in Armenia in the early twentieth century, but it was not used systematically and extensively until the Rwandan genocide (Mangassarian 2016:374).

Within the Rwandan genocide, rape specifically targeted women. Rwanda's patriarchal, militaristic society reinforces the notion that women are property and, therefore, are part of the plunder of war. The use of rape in Rwanda went deeper than just men satisfying their sexual needs "in a forceful demonstration of hyper masculinity," which often underlies rape in a domestic setting (Mullins 2009:721). Instead, rape was used to dehumanize and terrorize Tutsi women, by both common Hutu men and members of the Hutu militia (Totten and Ubaldo 2011: 31, 111). René Degni-Segui, the UN Special Rapporteur on human rights in Rwanda, stated, "rape was the rule and its absence was the exception," emphasizing the fact that almost all Tutsi females were raped during the genocide (1996). ${ }^{4}$ By analyzing the transcripts of trials against those involved in the Rwandan genocide, Christopher Mullins identified three specific types of rape: opportunistic rape, sexual enslavement, and genocidal rape (2009).

Opportunistic rape is defined as "sexual assaults that arise out of the general chaos and confusion of military engagement" (Mullins 2009:726). This type of rape presents itself not just in instances of genocide, but also in many wartime conflicts. In the context of the Rwandan genocide, opportunistic rape occurred the least frequently. Opportunistic rape relates closely to the "pressure cooker" theory of rape during wartime. According to this theory, men's instinctual sexual aggression mixed with the chaos of war and combat creates a "pressure cooker" which causes rape (Gottschall 2004:133).

Sexual enslavement describes situations in which one woman would experience multiple sexual assaults over a brief period of time while being confined, usually in the house of an Interahamwe soldier (Mullins 2009:727). This confinement separates sexual enslavement from other forms of rape. Additionally, sexually enslaved women were threatened with intense violence unless they gave into the will and requests of the soldiers. For example, one woman was threatened with being pierced by a spear after initially refusing sex (Mullins 2009:727).

Although cases of sexual enslavement most commonly occurred in Interahamwe houses, there are also cases which occurred in the homes of Hutus who were friends and neighbors of Tutsi families (Totten and Ubaldo 1999:111). During an interview, a man named Kwibuka recalled, "[Hutu neighbors and friends] often turned on [the girls and women] 
and raped them," and "demanded that women allow themselves to be raped as the price... for being hidden" (Totten and Ubaldo 1999:111). These instances show that raping Tutsi women became a fact of life for all Hutus, not just for militia members. Additionally, the quote referencing rape as the "price" for protection amongst friends and neighbors reveals the perceived entitlement of the Hutu men to the bodies of Tutsi women.

Genocidal rape differs from the other two categories because it specifically attempts to eliminate a population through violent and systematic rape. Mullins defines it as an "organized military tactic... used to generate fear in a subdued population, humiliate a population, derogate women, and create a cohort of mixed-ethnic children" (2009:721). Rape became normalized by local leaders, with rapists consisting of men of all classes and professions including soldiers, peasants, teachers, and priests (Sharlach 1999:394). In one instance, after finding a group of Tutsis, the commanding military leader told his troops to follow his example. He proceeded to rape and then stab one of the women. The soldiers followed his command and began raping and stabbing the women while shooting the men (Mullins 2009:728). Not only does this reveal military commands to rape women, but also it displays the increased amount of sexual violence women faced compared to men.

Rape was also used to accomplish the genocidal goal of preventing the birth of Tutsi babies. Initially, rape may not appear to prevent births, but, the violent nature of the rapes achieved this. Women were sometimes raped with spears and other sharp objects, resulting in their death or genital mutilation, which typically results in an inability for the woman to get pregnant (Mullins 2009: 727-729; Sharlach, 1999:396). Even in situations where Tutsi women did become pregnant, their child would be considered Hutu, as the legal ethnicity of a child in Rwanda is based on the father's ethnicity (Doná 2012:16). This further helped to prevent the birth of Tutsi children.

Although rape was the most widespread form of sexual violence committed against women, other forms of violence existed as well. The Interahamwe had an obsession with "what they did to women's bodies" (Sperling 2006:644). Hutu militiamen focused on mutilating women's breasts and vaginas. They poured acid and boiling water on women's vaginas, cut open pregnant women's wombs, and cut off women's breasts (Sperling 2006:645). In one instance, an Interahamwe soldier cut a mother's breast off and attempted to feed her baby with it (Mullins 2009:727).

Sexual violence during the Rwandan genocide encompassed debased actions of dehumanization that affected women more than men. One witness recalled four Interahamwe soldiers and an officer publicly raping a Tutsi woman repeatedly. The officer forced refugee women to watch the attack and told them they would later be killed (Mullins 2009:727). On multiple occasions, sons were forced to rape their mothers while their whole family would watch (Sperling 2006:644). The act of forcing a child to rape their mother shows barbarity on behalf of the soldiers and exposes the lack of acknowledgment of the Tutsi mother as human. In a survivor interview, Rose Marie Mukamwiza recounted being raped twice in front of her daughter Claire (Totten and Ubaldo 1999:31). Forcing other women, children, and 
families to watch rapes was common and added to the dehumanization of the women being raped; it shamed them, changing the way their children and community members viewed them.

As mentioned earlier, acts of genocide and sexual violence were committed by men of varied classes and professions. Rape became a hegemonic aspect of society; Hutu men used rape as a routine tool to dominate and destroy Tutsi women. The overwhelming majority of men who participated in the Rwandan genocide were ordinary men who did not have a history of violence or military involvement (Straus 2006:96). Many Hutu men joined militia groups out of fear of the punishment they could face for not getting involved (Straus 2006:96). However, this was not the only reason Hutu men became involved in attacks. Others chose to join the attacks to counter the advancement of Tutsi rebels, to steal goods from houses being ransacked, or due to deep loyalism to the Hutu ethnicity (Straus 2006:96). Although ordinary Hutu men made up the largest group of perpetrators of violence against women during the Rwandan genocide, Hutu women also played a key role as agents of violence against Tutsi women.

Even before the genocide, Hutu women were hostile towards Tutsi women. Prior to 1994, marriages between Tutsi and Hutus were legal, however, a marriage between a Hutu man and a Tutsi woman was more common than a marriage between a Tutsi man and Hutu woman (Fielding 2014:18). This resulted in some Hutu women harboring feelings of jealousy towards Tutsi women who were marrying and starting families with Hutu men. Additionally, a piece of Hutu propaganda entitled the "Hutu Ten Commandments" fostered Hutu women's animosity of Tutsi women. The first three commandments read:

1. Every Hutu male should know that Tutsi women, wherever they may be, are working in the pay of their Tutsi ethnic group. Consequently, shall be deemed a traitor: Any Hutu male who marries a Tutsi woman; Any Hutu male who keeps a Tutsi concubine; Any Hutu male who makes a Tutsi woman his secretary or protégée.

2. Every Hutu male must know that our Hutu daughters are more dignified and conscientious in their role of woman, wife or mother. Are they not pretty, good secretaries and more honest!

3. Hutu women, be vigilant and bring your husbands, brothers and sons back to their senses. ("The 'Hutu Ten Commandments' 1990)

The first two commandments imply that Tutsi women were dangerous to the morality and sensibility of Hutu men and that Hutu women are morally above Tutsi women. The third commandment directly calls upon Hutu women to take action to save their Hutu men. This document was initially published in 1959 and then republished in 1990 and spread throughout Rwanda (Brown 2014:455). This appeal for Hutu women to act against Tutsi women was revolutionary for Rwanda's patriarchal society (Brown 2014:455).

While this appeal for action was liberating for many Hutu women, it only further contributed to the violence against Tutsi women at the time. According to Sara Brown, 
the genocidal crimes committed by Hutu women during the Rwandan genocide can be split into two groups: direct acts of violence and indirect acts of violence (2014:457). Direct violence is defined as acts which require physical force, such as killing, rape, and sexual assault (Brown 2014:455). For example, a mother was put in jail for murdering her son who had a Tutsi father (Brown 2014:458). ${ }^{5}$ Indirect violence, on the other hand, involved looting, inciting violence, theft, and ordering direct violence. The majority of Hutu women committed indirect acts of violence, but some were involved in direct acts of violence (Brown 2014:455).

Much like with the male perpetrators, Hutu women across all classes and professions were involved in committing violence against Tutsi women. School girls killed their classmates, nuns turned in Tutsi refugees to the militia, and prostitutes killed Tutsi children (Sharlach 1999:392). Although there were few women involved in the government at the time, two women held immense power among the political elite during the genocide: Agathe Habyarimana, the wife of President Habyarimana, and Pauline Nyiramasuhuko, the Minister of the Family and Women's Affairs (Sharlach 1999:387). As part of the "little house," the group involved in planning the Rwandan genocide, the two women encouraged Hutu females to take part in the massacre of Tutsi women (Sharlach 1999:387).

Nyiramasuhuko played a particularly prominent role in inciting violence against Tutsi women. Throughout the genocide, she routinely drove around and spoke into a megaphone to encourage Hutus to rape and murder Tutsi women (Fielding 2014:28). In one instance, she allegedly ordered the militia to burn 70 women who were being kept by the government (Sperling 2006:650). Prior to burning them, she directed the men to rape the women and to keep the younger Tutsi women alive for sex (Sperling 2006:650).

Nyiramasuhuko was the only female accused in the International Criminal Tribunal for her involvement in the Rwandan Genocide (Drumbl 2013:562). Furthermore, she is the only woman to be convicted of genocide and rape as a crime against humanity by an international criminal tribunal (Drumbl 2013:562). Nyiramasuhuko serves as the most extreme case of a Hutu woman inciting sexual violence against Tutsi women, however, there were many ordinary women involved.

The effects of this sexual violence are still seen in Rwandan society today. Approximately 80 percent of female survivors were raped or sexually assaulted during the genocide (de Beer and Snyman 2015:117). ${ }^{6}$ The topic of rape is considered "taboo" in Rwanda and is not commonly discussed (de Beer and Snyman 2015:117). Many women have been stigmatized by their community because of their status a rape survivor, making it difficult for them to find stability and security (Holmes 2014:31). Additionally, a portion of female rape survivors faced the problem of unwanted and unplanned pregnancy. These pregnancies sometimes put the lives of the mothers at risk and resulted in a large number of orphaned children (Totten and Ubaldo 1999:59). Female survivors must also deal with long-term medical conditions which resulted from the genocide, such as HIV/AIDS and psychological problems (Sharlach, 1999:393). 
HIV/AIDS continues to impact the lives of thousands of women in Rwanda today. Infecting women with HIV/AIDS was often the goal of the rapist; men who knew they were HIV positive would deliberately not kill the women they raped (Sharlach 2000:99). Current Rwandan president Paul Kagame revealed that during the genocide, the previous government ordered hospitals to release AIDS patients to be used as agents of genocide (Sperling 2006:645). Mary Blewitt, a survivor of the genocide, recounted learning of many women who were raped and "spared so that they could die a slow death from HIV/AIDS" (Blewitt 2010:203). Over 67 percent of women raped during the genocide were infected with HIV and AIDS (Survivors Fund 2011). The Rwandan Widows' Association estimates around 70 percent of its 25,000 members are HIV positive as a direct result of being raped during the genocide (Hilsum 2004:913). Survivors claim that little is being done in Rwanda to prevent women from dying of HIV/AIDS. It is estimated that untreated HIV/AIDS can lead to death within 7 to 15 years (Sharlach 2000:100). Esther Mujawayo, a survivor, said "if you have not protected somebody in 1994, at least stop her dying now...women are still dying and again the world is watching" (Hilsum 2004:913). Treatment programs in Rwanda for HIV and AIDS do exist, but most of them do not prioritize the treatment of victims of genocidal rape (Hilsum 2004:913). This serves as an example of structural violence that currently exists within Rwanda. The government of Rwanda continues to allow for Tutsi women to face injustice in policies and programs.
In addition to women facing medical problems due to HIV/AIDS infections, many Tutsi women are plagued with psychological and mental problems due to their traumatizing experiences during the genocide (Sharlach 1999:393). One woman recalled that after her rapist forced her to watch her son get killed, he spared her and said, "You alone may live, only so that you will die of sadness" (Blewitt 2010:198). This exemplifies the mental torture many women were subjected to during the genocide. There are many accounts of men forcing Tutsi women to watch their husbands and children die. Although men in the genocide were also exposed to traumatic episodes, a study conducted by BMJ Open found Rwandan women to be more severely impacted by mental health issues (Krantz et al. 2015:1). This study found that men were exposed to slightly more traumatic experiences, such as witnessing mass killings, rape, and fleeing one's home, during the Rwandan genocide (Krantz et al. 2015:4). However, as of 2015, Rwandan women experience anxiety, PTSD, depression, and suicidal thoughts at rates double that of men (Krantz et al. 2015:10). Rose Marie Mukamwiza, the survivor who was raped in front of her daughter, has suffered nightmares and panic attacks directly tied to her experiences in the genocide (Totten and Ubaldo 1999:34). Her daughter goes into a state of intense depression and emotional instability every April (Totten and Ubaldo 1999:33). During this time, she spends weeks alone in her room and has sporadic outbursts of uncontrollable crying and screaming (Totten and Ubaldo 1999:34). Umulisa, another survivor, claims that the mental health of survivors is neglected (Totten and Ubaldo 
1999:63). According to her, most of those who assist survivors struggling with mental health issues are only trained for a few weeks.

Additionally, she claims there are under ten professional psychiatrists available for survivors in all of Rwanda (Totten and Ubaldo 1999:64). This limited access to mental health care contributes to the lasting impacts of the Rwandan genocide on women.

In addition to these troubles, many rape survivors lived in poverty and experienced chronic hunger and insecure housing immediately following the genocide (Zraly, Rubin, \& Mukamana 2013:414). However, Tutsi women did not allow the genocide to completely ruin their lives and keep them from working towards moving forward in their lives. Despite the immense burdens they faced post-genocide, Tutsi women remained resilient. Grassroots networks of female survivors began forming in the years after the genocide ended (Zraly, Rubin, \& Mukamana 2013:413). Through 12 years of research, ethnographers found three concepts within Rwandan culture which contributed to the resilience of these women: kwihangana, kwongera kubabo, and gukomeza ubuzima. Kwihangana involves finding strength within oneself to endure suffering, kwongera kubabo revolves around affirming the necessary existential conditions for being, and gukomeza ubuzima focuses on accepting struggles, surviving, and moving forward in life (Zraly, Rubin, \& Mukamana 2013:414).

Of the three, kwihangana is the most common, as it is present in everyday Rwandan life. The Rwandan word "ihangane" stems from kwihangana and means "be patient, be strong, withstand" (Zraly, Rubin, \& Mukamana
2013:414). This phrase is used to both calm people down in times of arguments and to console mourning family members, showing that the concept of kwihangana can be found in all aspects of one's life (Zraly, Rubin, \& Mukamana 2013:414). Because kwihangana is a form of resilience which is performed within oneself, it gives women the ability to regain a sense of confidence and emotional

independence. This is vital to a woman's ability to heal because it allows her to take back control of her body and mind.

In addition to finding resilience in traditional concepts of Rwandan culture, Tutsi genocide and rape survivors also found resilience in motherhood (Zraly, Rubin, \& Mukamana 2013:21). Alicia, a woman who was raped and lost her husband during the genocide, said, "now I say that God deserves thanks because... I still have my children, and this is enough to me" (Zraly, Rubin, \& Mukamana 2013:421). Her words reveal a mentality that many other women share. They find strength through their children and their determination to provide them with as stable and healthy a life as possible. Their ability to find a place for love and kindness in their lives and hearts after facing such unfathomable violence is reveals their persistent resilience.

The Rwandan genocide marked an incredibly dark time in history. Rwanda's patriarchal society was manifest in the form of intense sexual violence throughout the genocide. This was seen in the prevalence of genocidal rape and the gruesome mutilation and dehumanization of Tutsi women. These attacks were orchestrated by both Hutu men and Hutu women. However, even Hutu women were given only limited freedom in to carry out 
the genocidal plans of the government. Thousands of Tutsi women died as a result of violent rapes and attacks, and those that survived are afflicted with both physical and mental health problems today. Still, many of these women have been able to move forward in their lives. The entire country of Rwanda has been taking steps to rebuild their nation in the wake of the genocide. Each month, villages require able-bodied Rwandan citizens to participate in at least three hours of community service (Specia 2017). This program, instituted by president Kagame, is one of many exercises created to help foster reconciliation within the nation.

Although Rwanda has been working toward rebuilding their nation and citizens since 1994, other parts of the world are still plagued with overwhelming amounts of sexual violence directed at women. Twenty years after the Rwandan genocide, formed UN Secretary-General Ban Ki-moon reaffirmed the international community's dedication to "never again" allow genocide and genocidal rape to occur (Tompson 2017). Unfortunately, such acts have occurred since Ki-moon's speech, notably in Syria and Iraq with the rise of ISIS (Tompson 2017). Girls and women are reportedly being sold to ISIS members, sexually assaulted, raped, and forced into marriage in Iraq and Syria currently (Tompson 2017). International organizations, notably the United Nations, need to speak out against the sexual abuse women continue to face and take action against these attacks. Much of the world idly watched as thousands of Rwandan Tutsi females were raped, mutilated, and violated. The world has a chance to stop such actions from occurring to women and girls in Syria and
Iraq. However, they must act soon if they want to stop history from repeating itself. NOTES:

${ }^{1}$ Background information including statistics on the number of people killed in and the time frame of the Rwandan genocide can be found in Hoex \& Smeulers 2010; Straus 2006; and United Nations 2014.

${ }^{2}$ It should be noted that the Rwandan genocide was not the first recorded instance of women facing sexual assault directly related to genocidal actions. Notably, the UN estimates around 60,000 women were raped during the Bosnian genocide (United Nations 2014). However, the number of women raped during the Rwandan genocide is estimated to be at least four times this number (United Nations 2014).

${ }^{3}$ The remaining one percent of the Rwandan population was Batwa or Twa, an indigenous group in Rwanda (Hoex \& Smeulers 2010:438). Although they were impacted by the genocide, they were generally not overtly involved in the conflict, and therefore will not be included in the analysis.

${ }^{4}$ Although Tutsi women were the main targets of most rapes, it's necessary to note that some Hutu women were also raped during the genocide. Most commonly, these rapes occurred if Hutu women were associated with Tutsis, remained complacent during attacks, or were simply in the wrong place at the wrong time (Sharlach 1999:388).

${ }^{5}$ When studying direct acts of violence committed by women in the Rwandan genocide, it is vital to note that there are recorded, isolated instances of Hutu women taping Tutsi men and boys (Brown 2014:459). However, these should not be considered genocidal rape because it was not organized as a widespread tactic to kill and dehumanize Tutsi men. 
${ }^{6}$ Women who were not raped still faced problems in Rwandan society post genocide. For example, in 1992 21\% of women in Rwanda were widowed; by $1994,36 \%$ of women were widowed (Holmes 2014:31). Not all of these women were rape survivors, yet they still faced issues of stability due to the death of their husbands. However, most available research focuses on the effects of the survivors of sexual violence, so I will focus this section on these women.

\section{References}

Blewitt, Mary K. You Alone May Live. London: Dialogue, 2010.

Brown, Sara E. "Female Perpetrators of the Rwandan Genocide." International Feminist Journal of Politics 16 (2014): 448-69.

Bureau of Democracy, Human Rights, and Labor, comp. Rwanda Country Report on Human Rights Practices for 1996. U.S. Department of State, 1997.

Convention on the Prevention and Punishment of the Crime of Genocide. Publication no. 1021. United Nations, 1948.

de Beer, Anna-Marie, and Elisabeth Snyman. "Shadows of Life, Death and Survival in the Aftermath of the Rwandan Genocide." Tydskrif vir Letterkunde; Journal of Literature 52, no. 1 (2015): 113-30.

Degni-Ségui, Rene, comp. Report on the Situation of Human Rights in Rwanda. Report no. E/CN.4/1996/68. United Nations, 1996.
Doná, Giorgia. "Being Young and of Mixed Ethnicity in Rwanda." Forced Migration Review, no. 40 (August 2012): 16-17.

Drumbl, Mark. "'She Makes Me Ashamed to Be a Woman': The Genocide Conviction of Pauline Nyiramasuhuko, 2011." Michigan Journal of International Law 34, no. 3 (Spring 2013): 559-603.

Fielding, Leila. Female Genocidaires during the Rwandan Genocide: When Women Kill. Hamburg: Anchor Academic Publishing, 2014.

Gottschall, Jonathan. "Explaining Wartime Rape." The Journal of Sex Research 41, no. 2 (May 2004): 129-36.

Hilsum, Lindsey. "Rwandan Genocide Survivors Denied AIDS Treatment." British Medical Journal 328, no. 7445 (April 17, 2004): 913.

Hoex, Lotte, and Alette Smeulers. "Studying the Microdynamics of the Rwandan Genocide." The British Journal of Criminology 50, no. 3 (May 2010): 435-54.

Holmes, Georgina. Women and War in Rwanda: Gender, Media, and the Representation of Genocide. New York: I.B. Tauris, 2014.

"The 'Hutu Ten Commandments'." Kangura, no. 6 (December 1990).

Krantz, Gunilla, Ingrid Mogren, Joseph Ntaganira, and Lawrence Rugema. "Traumatic Episodes and Mental Health Effects in Young Men and Women in Rwanda, 17 Years after the Genocide." BMJ Open 5, no. 6 (2015). 
Mangassarian, Selina L. "100 Years of Trauma:

The Armenian Genocide and Intergenerational Cultural Trauma." Journal of Aggression, Maltreatment and Trauma, 25, no. 4 (2016): 371-81.

Mullins, Christopher W. "'We Are Going to Rape You and Taste Tutsi Women': Rape during the 1994 Rwandan Genocide." The British Journal of Criminology 49, no. 6 (November 2009): 719-35.

Sharlach, Lisa. "Gender and Genocide in Rwanda: Women as Agents and Objects of Genocide." Journal of Genocide Research 1, no. 3 (1999): 387-99.

Sharlach, Lisa. "Rape as Genocide: Bangladesh, the Former Yugoslavia, and Rwanda." New Political Science 22, no. 1 (2000): 89-102.

Specia, Megan. "How a Nation Reconciles after Genocide Killed Nearly a Million People." New York Times, April 25, 2017, Africa. Accessed April 28, 2017. https://www.nytimes.com/2017/04/25/w orld/africa/rwandans-carry-on-side-by-s ide-two-decades-after-genocide.html.

Sperling, Carrie. "Mother of Atrocities: Pauline Nyiramasuhuko's Role in the Rwandan Genocide." Fordham Urban Law Journal 33, no. 2 (January 2006): 637-64.

Straus, Scott. "The Genocidaires." In The Order of Genocide: Race, Power, and War in Rwanda, 95-121. Cornell University Press, 2006.
Survivors Fund. "Rwandan History: Statistics." Supporting Survivors of the Rwandan Genocide. Last modified 2011. http://survivors-fund.org.uk/resources/r wandan-history/statistics/.

Taylor, Christopher C. "A Gendered Genocide: Tutsi Women and Hutu Extremists in the 1994 Rwanda Genocide." Political and Legal Anthropology Review 22, no. 1 (May 1999): 42-54.

Tompson, Alexandra. "After the Rwandan Genocide the UN Promised 'Never Again' - Now It's Time for Them to Take Action against ISIS." Forbes, April 20, 2017, Foreign Affairs. Accessed April 28, 2017. https://www.forbes.com/sites/realspin/2 017/04/20/after-the-rwandan-genocide-t he-un-promised-never-again-now-its-ti me-for-them-to-take-action-against-isis/

Totten, Samuel, and Rafiki Ubaldo, eds. We Cannot Forget: Interviews with Survivors of the 1994 Genocide in Rwanda. New Brunswick, NJ: Rutgers University Press, 2011.

United Nations. "The Justice and Reconciliation Process in Rwanda." Outreach Programme on the Rwanda Genocide. Last modified 2014. Accessed April 23, 2017. http://www.un.org/en/preventgenocide/r wanda/about/bgsexualviolence.shtml.

Zraly, Maggie, Sarah E. Rubin, and Donatilla Mukamana. "Motherhood and Resilience among Rwandan Genocide-Rape Survivors." Ethos 41, no. 4 (December 2013): 411-39. 